\title{
Discussion on Advanced Programming Language Courses Grades Teaching in Agricultural and Forestry University
}

\author{
Aiguo Zhang, Ping Song, Lanling Jiang \\ College of Information and Electrical Engineering, Shenyang Agricultural University, Shenyang, China \\ Email: zhangaiguo1968@163.com
}

Received 2012

\begin{abstract}
In view of students' Advanced Programming Language of different level in the higher forestry college, the implementation graded layers teaching can well realize the modern teaching concept which taking the student as the main body, and truly improve the quality of Advanced Programming Language courses teaching to better meet the forestry and professional talent training needs of society. Advanced Programming Language course grade teaching in the higher forestry college needs to solve the teachers' quality and teaching cost, teaching management and the students' psychological and other major issues. It needs to strength teaching concept of human-oriented, improve teachers teaching level; scientific choose or write teaching material, carefully plan and design teaching content, Increase the teaching software and hardware facilities investment, improve the modern teaching management level; Strengthen teacher humanistic care consciousness and strengthen students' physical and psychological health level.
\end{abstract}

Keywords: Advanced Programming Language; Grades Teaching; Agricultural and Forestry University

\section{Introduction}

Along with the popularization of computer technology and the rapid development of the information industry, especially the development of agricultural information technology, more and more people are aware of the computer in the process of modernization of agriculture plays an important role [1]. As the technology tools in the area of agricultural information, the application of computer in agriculture has been regarded as an important symbol for measuring the modern agriculture, computer technology has become the modern quality standard for measuring the people in the area of modern agriculture. In recent years, as a result of college enrolment expansion, the base education of non computer major falls in embarrassment, college students' computer knowledge and application ability is put in bigger difference; knowledge is not fully used in professional and social practice and so on, causes the teachers and students in teaching and learning process in a confusing [2].

Aiming at different levels of computer basic knowledge college students in agriculture and forestry colleges and professional demand difference, implementation of hierarchical teaching can better realize of computer basis teaching breakthroughs, realize modern teaching concept of people-oriented and take the student as the main body, truly improve the teaching quality of computer foundation course, to better meet the professional needs and social needs.

\section{Theoretical Basis of Implementation of Hierarchical Teaching}

Learning motivation is the inner psychological motivation to cause and sustain students' learning behaviour, and take the behaviour to tend to certain objectives. According to "Selfefficacy Theory"[4] of the United States psychologists, human behaviour will be impacted by the results and antecedent factors. If people predict to a particular behaviour will lead to a particular outcome, then it may be activated and selected. In the college, students' learning motivation are more diversified, personalized and complicated, so to improve the quality of teaching basic computer courses, teachers must first understand students' learning motivation and stimulate learning motivation, let the students have a high degree of sense of self-efficacy to active learning in Computer Basic knowledge and basic skills.

\section{The Necessity of Implementation of Hierarchical Teaching}

The present analysis of advanced language program design of non computer majors in Colleges and universities of agriculture and forestry The level of the teaching target who is sophomore is uneven. The calendar year exam score distributions show: achievement and source zones and their professional correlated significantly, poor students mostly from remote and impoverished area, better performance of students, mostly from the developed areas; Agriculture Automation, information and computing science, biological engineering are higher in computer programming ability than other professional students such as Agriculture and Forestry Science.

The present analysis of teaching of non computer majors in Colleges and universities of agriculture and forestry Many colleges and universities of agriculture and forestry adopt uniform teaching syllabus, teaching notes and performance assessment, which result in students in the learning process appear more obvious polarization phenomenon. In the concrete teaching, due to backward textbook and curriculum unreasonable factors, various schools and professional teaching content is not different. Teaching plan is not suit to the needs of society and professional needs and can not directly serve the needs of professional, leading to "learn to use separation", also reduced the students' learning enthusiasm and initiative.

Oneself demand analysis of non computer majors in Colleges and universities of agriculture and forestry In 2010, we con- 
ducted questionnaire and random sampling in Shenyang Agricultural University, the results showed: $94.5 \%$ of the students thought they were interested in advanced language program design, $15.2 \%$ of the students thought it is quite easy to learn, $25.2 \%$ of them thought it is more difficult, which has $9.4 \%$ of them thought it cannot be started. For advanced language program design course, the teacher should how to "teach", students should be how to "learn”, students' own suggestions: first, hierarchical teaching; second, increase the practice time and content; third, increase practical training content as a public elective course. The findings show that, students have strong learning desire, but the current teaching mode can't meet the needs of students of knowledge, cannot reflect the profound meaning of quality education, so the implementation of hierarchical teaching is students' learning of basic computer courses in their own needs.

\section{The Principle and Method of Implementation of Hierarchical Teaching}

\section{The Principle of Implementation of Hierarchical Teaching}

First of all, agriculture and forestry colleges need to change concept, innovate the mode of talent training, should adopt modern teaching concepts such as "student-centered, teacher-led" and "taking application as the purpose and tanking practice as the target”, emphasizing the Main body position of the students in the teaching activity, give full play to the initiative of student learning, stimulate students innovation [5]. On the teaching mode and teaching method, aiming at the student level, using different teaching methods and means, according to different students, using lectures, guided, upper class demonstration operation content, to the different student classification guidance. At the same time, make full use of network teaching resources in classroom, let students autonomous learning. Thus, in the teaching content, teaching method and teaching mode, is formed with the students as the center, forming students' autonomous learning, teachers' guidance, teaching at different levels, in order to satisfy the need of different subject

Secondly, according to the different major have different advanced language programming course, such as: agriculture, management open "Visual Foxpro", mechanism, water conservancy open "Visual Basic", information and computation science open "C language", etc. At the same time, should choose textbook suitable for students in agriculture and forestry colleges, teaching content, material selection, sample should be close as possible to the agricultural and forestry specialty.

\section{The Method of Implementation of Hierarchical Teaching}

According to the different major, students should be divided into four classes A, B, C, D. Class A as a bias towards arts, open "Visual Foxpro"; Class B as a bias towards engineering open "Visual Basic"; Class C as a bias towards science open " $\mathrm{C}$ programming language"; D is biased information open "Java programming". Each class should be divided into two levels. The first level start from basic education, learn the basic methods and basic skills; the second levels from the programming skills to learn the application of relevant and professional. According to the four categories and two levels, combined with the professional direction, according to the similarity principle placement, teach students in accordance with their aptitude, meet the needs of different students' learning needs.

In the hierarchical teaching design, should adopt studentcentered, teacher-led teaching principle and establish corresponding teaching method and mode with graded-teaching, modify teaching syllabus, perfect the evaluation standard, so that all students can stimulate good learning motivation, to produce the greatest sense of self-efficacy.

\section{The Main Program Need to Solve in Implementation of Hierarchical Teaching}

\section{The Quality of Teachers}

Hierarchical teaching requires sufficient quantity of the teacher and the teacher must have a wide range of knowledge. Facing different levels of students, teachers should have the corresponding teaching ideas and teaching methods, it is inevitable to put forward higher requirements to computer basic course teachers. But now, teachers and the quality are facing serious problems in Agricultural and Forestry College's computer basic course. Taking Shenyang Agricultural University as an example, school enrolment has increased year by year, but the number of teachers engaged in teaching basic computer is decreasing, especially the severe shortage of teachers, resulting in age structure, professional title structure unreasonable factors, teachers' knowledge is obsolete, the teaching idea and teaching method is backward, the overall quality is not to improve the [7].

\section{The Teaching Cost}

Hierarchical teaching activities need to break the normal procedure of teaching management, demand more multimedia classroom and computer room. In addition, in order to improve the overall quality of the teachers, adjusting teacher's age structure, knowledge structure and professional title structure, should timely bring in teachers, form reasonable teaching echelon; at the same time, should send backbone teachers to join modern education training for perfecting the knowledge structure of teachers. All of these will increase the cost of teaching.

\section{Students' Psychology}

In the university stage, the students will have to study more courses and be with strong independence and initiative, many students can not adapt to the learning method. Secondly, many students cannot adapt to the collective life in the university, lack of self management and self service ability of students is a grim challenge, many students don't know how to adapt the loss in the psychological sense of oppression [8]. In particular the hierarchical teaching, they have to leave the original natural class, it make some students in the interpersonal aspects appear confused with each other, the thoughts and feelings are of lack of timely communication and expression, it leads to loneliness, depression and feelings of inferiority.

\section{The Main Strategy in Implementation of Hierarchical Teaching}

\section{Strengthen People Oriented Teaching Concept, Enhance Teachers' Teaching Level}

The modern concept of teaching in higher education should be based on the students, strengthen the people oriented teach- 
ing concept, strengthening the basic subject and subject binding. The school should have regular introduction of highly educated young teachers enrich basic computer teaching team, send young backbone teachers to join modern education training to enrich the academic level, renew knowledge of the teachers. In short, the school should take strong measures to strengthen the building of the contingent of teachers, comprehensively enhance the level of teaching staff, construct high-quality teachers of computer foundation.

\section{Scientifically Choose Textbook, Carefully Plan and Design Teaching Content and Teaching Method}

Schools should set up a scientific teaching evaluation system, according to the teaching syllabus and teaching plan, try to choose the National Publishing House of the national planning textbook. In order to improve the practicality of the teaching material, the school should encourage teachers to compile textbook, improve the quality of the textbook and teachers' overall quality and level.

The school should change idea focusing on the talent training goal, in the ideology, advocate the traditional teaching method and modern teaching mode combining with teaching reform project, encourage and promote teachers to use advanced and flexible teaching methods and means of teaching to arouse students' learning interest. In teaching methods, the school should bold explore and attempt, effort to promote multimedia teaching, network teaching and other modern education means, explore bilingual teaching to the high-level students, cultivate students' autonomous learning and creative thinking ability [9].

\section{Increase the Teaching Hardware and Software Facilities; Improve the Modernization Level of Teaching Management}

The school should strengthen the modernization of teaching equipment investment, regular updates the engine room equipment to guarantee the students' experimental machine; educational departments should cooperate with the computer basis teaching and research section to finish grading and grouping work, reasonably arrange the multimedia classroom, rationally allocate and use of teaching resources.

\section{Strengthen Teachers' Humanities Concern Consciousness; Strengthen the Students' Physical and Mental Health}

The school depends on the quality of teachers, it determines the quality of school teaching level, determines the students' overall quality and ability, which requires schools to concern of teachers work and life. The school should solve the teacher's worries behind, fully mobilize the enthusiasm of teachers, can make the teacher take the energy to the teaching reform and practice, enhance the overall level of teachers and the quality.

The school should increase education strength, strengthen student's ideal and belief, advance specialized ideological education, plan career, to guide students to establish the concept of lifelong learning and independent learning. At the same time, strengthen ideological and political work, pay attention to the humanistic care and psychological guidance, adhere to the people-oriented education concept, prompt the overall development of students, especially to care for vulnerable groups, to promote the harmonious development of the campus.

\section{Conclusions}

In short, implementing graded teaching for Advanced Programming Language in agricultural and forestry colleges, not only is beneficial to the teachers to carry out teaching activities, also can make students with different knowledge can obtain greater progress and improve in learning computer courses. This is a "student-centered, teacher-led" teaching strategy, fully embodies the principle of teach students in accordance with their aptitude.

\section{REFERENCES}

Krashen S. Second Language Acquisition and second Language Learning .Oxford: Pergamon Press,981.

Bandura A. Self-efficacy mechanism in human agency .The American Psychologist, 1982,37(2):122-147.

Qin Falan, Xu Liqiong . The Post Graduates in Universities of agriculture and Forestry College English teaching to explore $[\mathrm{J}]$. higher agricultural education,2010, (1) :65-67.

Geng Yu." University Computer Basis" grading teaching [J]. Journal of Xiangfan Vocational and Technical College,2006, (6) :73-75.

Dong Hongye. Basic computer teaching basic requirements, basic computer education in Liaoning province the speech on annual meeting,2009

Qinyan new period of practice teaching of agricultural colleges and universities work discussion, [J]. Journal of Shenyang Agricultural Uinversity,2011(3):328-330

Zhang Aiguo, agricultural college computer basic curriculum reform on practice, [J]. higher agricultural education,2011(7):51-52,95

$\mathrm{Xu}$ Kunpeng, of university freshmen education important content, [J]. Journal of Shenyang Agricultural Uinversity,2011(2):189-192

Jiang Lanling, Zhang Aiguo and other university computer basis teaching model of higher agricultural education, [J],2011(9):53-55

Yang Pei, Liang Chunquan, Wei Lei . Higher agricultural colleges computer basic teaching reform explore [J], Anhui Agricultural Science Bulletin,2008,14(15) :224-226. 